Published every April, August and December

JURNAL RISET AKUNTANSI \& KEUANGAN

ISSN:2541-061X (Online). ISSN:2338-1507(Print). http://ejournal.upi.edu/index.php/JRAK

\title{
Pengaruh Laba Akuntansi, Komponen Arus Kas, dan Dividend Yield Terhadap Return Saham (Studi pada Perusahaan Sektor Pertambangan di Bursa Efek Indonesia Periode 2012-2014)
}

\author{
Yogie Rahmanda Putra ${ }^{1}$, Mimin Widaningsih ${ }^{2}$ \\ Program Studi Akuntansi, FPEB, Universitas Pendidikan Indonesia, Bandung, Indonesia
}

\begin{abstract}
This study aims to analyze the effect of Accounting Profit, Cash Flow Component, and Dividend Yield to Return of Stock at Mining companies listed in Indonesia Stock Exchange period 2012-2014. The variables studied in this study are accounting profit, operating cash flow, investment cash flow, cash flow financing, and dividend yield as independent variable; Stock Return as a dependent variable. The research method used is descriptive statistical method. With verifikatif testing using multiple regression (multiple regression). The data used is secondary data that is the annual report of the company that used as sample in research. The sample of research is 12 Mining Sector companies listed in Indonesia Stock Exchange Year 2011-2014 taken by using purposive sampling method. The results of this study indicate that the accounting profit, operating cash flow, cash flow investment, cash flow funding, and Dividend yield positive effect on stock Return.

Keywords:Accounting profit; Cash flows investment; Operating cash flow; Cash flow funding; Dividend yield; Stock Return

Abstrak.Penelitian ini bertujuan untuk menganalisis pengaruh Laba Akuntansi, Komponen Arus Kas, dan Dividend Yield terhadap Return saham pada perusahaan Pertambangan yang terdaftar di Bursa Efek Indonesia periode 2012-2014. Variable yang diteliti dalam penelitian ini adalah Laba akuntansi, Arus kas operasi, Arus kas investasi, Arus kas pendanaan, dan Dividend yield sebagai variable independen; Return Saham sebagai variable dependen. Metode penelitian yang digunakan adalah metode statistik deskriptif. Dengan pengujian verifikatif menggunakan regresi berganda (multiple regression). Data yang digunakan merupakan data sekunder yaitu laporan tahunan perusahaan yang dijadikan sampel dalam penelitian. Sampel penelitian merupakan 12 perusahaan Sektor Pertambangan yang terdaftar di Bursa Efek Indonesia Tahun 2011-2014 yang diambil dengan menggunakan metode purposive sampling. Hasil penelitian ini menunjukkan bahwa Laba akuntansi, Arus kas operasi, Arus kas investasi, Arus kas pendanaan, dan Dividend yield berpengaruh positif terhadap Return saham. Kata Kunci: Arus kas investas; Arus kas operas; Arus kas pendanaan; Dividend yield; Laba akuntansi; Return saham
\end{abstract}

Corresponding author. Email: ${ }^{1}$ yogieerpee@gmail.com, ${ }^{2}$ mimin.widaningsih@upi.edu. Jalan Setiabudi No.229, Isola, Sukasari, Kota Bandung, Jawa Barat 40154

How to cite this article. Yogie Rahmanda Putra, M. W. (2016). Pengaruh Laba Akuntansi, Komponen Arus Kas, dan Dividend Yield Terhadap Return Saham (Studi pada Perusahaan Sektor Pertambangan di Bursa Efek Indonesia Periode 2012-2014). Jurnal Riset Akuntansi Dan Keuangan Program Studi Akuntansi Fakultas Pendidikan Ekonomi Dan Bisnis Universitas Pendidikan Indonesia, 4(2), 1047-1058. Retrieved from http://ejournal.upi.edu/index.php/JRAK/article/view/4039

History of article. Received: Mei 2016, Revision: Juli 2016, Published: Agustus 2016

Online ISSN: 2541-061X.Print ISSN: 2338-1507. DOI: 10.17509/jrak.v4i2.4039

Copyright@2016. Jurnal Riset Akuntansi dan Keuangan Program Studi Akuntansi FPEB UPI 


\section{PENDAHULUAN}

Pasar modal di Indonesia dianggap sebagai salah satu indikator ekonomi dalam suatu perkembangan negara. Seperti yang dikatakan Widoatmodjo (2012) Pasar modal merupakan suatu lembaga yang bergerak untuk mengalirkan dana masyarakat dengan menyediakan sarana untuk mempertemukan penjual dan pembeli dana-dana jangka panjang.

Investor harus memiliki informasi guna mendapatkan penilaian terhadap resiko yang ada dalam investasinya dan juga menganalisis return yang akan didapatnya. Informasi yang harus dimiliki investor salah satunya adalah informasi tentang keadaan umum ekonomi dan hasil sekuritasnya, hal ini bisa diperoleh dari jurnal, majalah ekonomi atau pun bsnis ekonomi. Investor juga harus mengetahui informasi mengenai keuangan yang tentunya diperoleh dari laporan keuangan. Laporan keuangan diperoleh dari hasil akhir dari proses akuntansi dan ini memang dirancang untuk menyediakan kebutuhan informasi guna memperkirakan prospek pertumbuhan perusahaan. Laporan keuangan sangat berguna juga bagi kreditor atau pengguna eksternal lainnya untuk mengambil keputusan. Soemarso (2005) mengatakan Laporan keuangan adalah laporan yang dirancang untuk para pembuat keputusan, terutama pihak di luar perusahaan, mengenai posisi keuangan dan hasil usaha perusahaan. Seperti yang telah disebutkan bahwa perdagangan saham pada era ini memang sangat pesat oleh karena itu tinggi pula tingkat risiko saham, maka kebutuhan akan informasi yang akurat untuk investor dalam pengambilan keputusan juga meningkat. Informasi ini diperlukan untuk mengetahui variabel-variabel yang berhubungan dengan fluktuasi harga saham dan hubungan dengan variabel.

Menurut analis Vibiz Research dari Vibiz Consulting (2015) mengulas pergerakan saham pada industri tambang mengatakan bahwa jika ingin mengetahui saham favorit di bursa saham Indonesia maka saham-saham tersebut ada di sektor perbankan, properti dan juga pertambangan. Di industri ini cukup banyak saham yang dapat dikatakan blue chip dan termasuk ke dalam LQ45 atau pernah masuk ke dalam LQ45. Walaupun salah satu yang menjadi favorit bagi investor, namun saham-saham industri tambang pada triwulan kedua tahun 2014 memiliki kinerja yang menurun. Dari sisi fundamental, tetap harus disadari bahwa sektor pertambangan sekarang ini tetap menjadi salah satu sektor utama yang menggerakkan roda perekonomian Indonesia. Indikasi ini terlihat dari kontribusi penerimaan negara yang setiap tahunnya meningkat. Selain itu, sektor pertambangan juga memberikan efek pengganda 1,6-1,9 atau menjadi pemicu pertumbuhan sektor lainnya serta menyediakan kesempatan kerja bagi sekitar 34 ribu tenaga kerja langsung.

Untuk penelitian ini variabel-variabel yang digunakan adalah arus kas yang terdiri dari arus kas operasional yang diukur berdasarkan perubahan modal kerja. Hubungan arus kas operasi dengan return dapat dijelaskan melalui hasil studi Rayburn (1986) yang menunjukan adanya hubungan antara arus kas dari kegiatan operasi dan laba akrual terhadap return saham. Lalu arus kas pendanaan, Arus kas pendanaan berguna untuk memprediksi klaim terhadap arus kas masa depan oleh para pemasok modal perusahaan. Miller dan Rock (1985) dengan signaling theory menjelaskan bahwa pasar bereaksi negatif terhadap pengumuman pendanaan dari kas, dan arus kas investasi yang merupakan peningkatan atas asset tidak lancar dan juga peningkatan investasi pada anak perusahaan, aktivitas investasi adalah aktivitas yang menyangkut perolehan atau pelepasan aktiva jangka panjang dan investasi lain yang tidak termasuk dalam setara kas, mencakup aktivitas meminjamkan uang dan mengumpulkan piutang, memperoleh atau menjual investasi dan aktiva jangka panjang. Penelitian ini juga menggunakan variabel laba akuntansi dan dividend yield. Informasi laba akuntansi sering diragukan akurasi dan obyektifitasnya karena komponen akrualnya. Laba akuntansi yang meningkat dapat memberikan sinyal positif kepada investor mengenai prospek dan kinerja perusahaan di masa depan, sehingga investor tertarik membeli saham tersebut. Adanya aktivitas 
tersebut menyebabkan harga saham mengalami kenaikan yang pada akhinya meningkatkan return sahamnya. Dan juga Divident Yield menunjukkan hubungan antara dividen yang dibayarkan untuk setiap satu lembar saham biasa dan harga pasar saham biasa per lembar. Semakin besar nilai Divident Yield menunjukkan perusahaan mampu menghasilkan kentungan yang besar.

Sinyal berupa good news atas informasi yang diperoleh investor dari laporan keuangan akan meningkatkan penilaian investor sebagai salah satu pengguna laporan keuangan terhadap kinerja perusahaan. Informasi mengenai kinerja keuangan dapat diperoleh melalui analisis laporan keuangan, menurut Hendry Andreas (2013) menyatakan bahwa analisis laporan keuangan dapat membantu untuk mengetahui apakah tingkat kinerja keuangan perusahaan baik atau sebaliknya.

Menurut Robert Ang (1997) menyatakan bahwa setiap investasi baik jangka panjang maupun jangka pendek mempunyai tujuan utama untuk mendapatkan keuntungan yang disebut return. Untuk itu peneliti memfokuskan penelitian ini pada sisi fundamental perusahaan yakni kinerja keuangan yang dilihat dari analisis rasio laporan keuangan dan dinilai dapat mempengaruhi return saham pada perusahaan yang berada disektor tambang.

Penelitian ini merupakan pengembangan dari beberapa penelitian terdahulu, seperti penelitian Suriani Ginting (2011) penelitiannya menggunakan variabel rasio rasio keuangan arus kas dan laba akuntansi saja dan tidak menggunakan variabel dividend yield. Penelitian yang dilakukan Jundan Adiwiratama (2012) yang menggunakan variabel arus kas, laba bersih serta ukuran size sebagai variabel independennya tetapi tidak menggunakan variabel dividen. Perbedaan penelitian ini dengan penelitian terdahulu yaitu penelitian ini hanya fokus pada perusahaan sektor pertambangan dikarenakan sektor ini mempunyai peran besar dalam perekonomian Indonesia dan harga sahamnya dari tahun ke tahun mengalami fluktuatif dan penelitian ini menggunakan variabel dividend yield sebagai objek penelitian. Penelitian juga menggunakan data terbaru pada sektor pertambangan yaitu tahun 2011-2014.

Seperti yang telah dijelaskan keadaan harga saham yang naik turun akan berdampak pada return saham itu sendiri. Dari masalah ini pemegang saham harus bisa memprediksi dengan baik dengan menganalisis apa yang akan terjadi di masa yang akan datang. Hal yang dapat mempengaruhi harga saham contoh dalam intern perusahaan seperti prospek perusahaan, keahlian manajemen perusahaan dalam menjalankan kegiatan operasinya dan eksternal perusahaan contohnya seperti inflasi, perubahan kurs dan politik. Penelitian ini sangat menarik bagi penulis dikarenakan dalam penelitian terdahulu masih tidak konsisten dari hasil yang didapat. Untuk itu, peneliti memfokuskan penelitian ini pada sisi fundamental perusahaan yakni kinerja keuangan yang tercermin dari analisis laporan keuangan dan dinilai dapat mempengaruhi return saham diantaranya: Bagaimanakah Pengaruh Laba Akuntansi terhadap return saham, Bagaimanakah Pengaruh Arus Kas Operasi terhadap return saham, Bagaimanakah Pengaruh Arus Kas investasi terhadap return saham, Bagaimanakah Pengaruh Arus Kas pendanaan terhadap return saham, Bagaimanakah Pengaruh Dividend Yield terhadap return saham. penelitian ini bertujuan untuk memberikan bukti empiris mengenai pengaruh faktor intern dalam perusahaan terhadap return saham di Indonesia. Pemahaman terhadap kegiatan operasional dalam suatu perusahaan sangat penting karena berkaitan dengan return saham.

\section{KAJIAN LITERATUR}

\section{Laba Akuntansi}

Menurut IAI, income didefinisikan sebagai berikut : "income merupakan kenaikan manfaat ekonomi selama satu periode akuntansi dalam bentuk pemasukan atau penambahan aktiva atau penurunan kewajiban yang mengakibatkan kenaikan ekuitas yang tidak berasal dari kontribusi penanaman modal" Laba akuntansi secara operasional didefinisikan sebagai perbedaan 
antara pendapatan yang direalisasi yang timbul dan transaksi periode tersebut dan biaya historis (Belkaoui, 2000).

\section{Teori Arus kas}

Laporan arus kas (statement of cash flows atau cash flow statement) adalah laporan yang menyajikan ikhtisar terinci mengenai semua arus kas masuk dan arus kas keluar, atau sumber dan penggunaan kas selama suatu periode (IAI, 2007). Bagi pemakai laporan keuangan informasi arus kas sangat penting untuk mengetahui ukuran dan kemampuan perusahaan dalam menghasilkan kas dan setara kas.Tujuan utama laporan arus kas adalah menyediakan informasi yang relevan mengenai penerimaan dan pembayaran kas sebuah perusahaan selama suatu periode.

\section{Arus kas Operasi}

Arus Kas Operasi (operating activities) meliputi kas yang dihasilkan dan dikeluarkan yang masuk dalam determinasi penentuan laba bersih. Arus Kas yang berasal dari (digunakan untuk) aktivitas operasi meliputi arus kas yang timbul karena adanya pengiriman atau produksi barang untuk dijual dan penyediaan jasa, serta pengaruh transaksi dan peristiwa lainnya terhadap kas yang mempengaruhi pendapatan.

Menurut PSAK 2 (2007) Aktivitas penghasil utama pendapatan entitas dan aktivitas lain yang bukan merupakan aktivitas investasi dan pendanaan. Indikator utama menentukan apakan operasi dapat menghasilkan kas untuk melunasi pinjaman dan memelihara kemampuan operasi entitas, membayar deviden dan melakukan investasi. Dalam aliran masuk modal nya terdiri dari inflows dan outflows.Inflows terdiri dari : (1) Penerimaan dari penjualan barang/jasa, royalti, pendapatan lain (2) Penerimaan dari pendapatan sewa, restitusi pajak (3) Penerimaan dari pemberian untuk bank dan penjualan sekuritas dari perusahaan efek

Outflows terdiri dari (1) Pembayaran untuk karyawan. (2) Pembayaran klaim (asuransi),pembelian efek (perusahaan efek), pengembalian kredit (bank) (3) Pembayaran biaya operasi (4) Pembayaran kepada pemasok barang dan jasa.

\section{Arus kas Investasi}

Arus Kas Investasi merupakan arus kas yang mencerminkan penerimaan dan pengeluaran kas sehubungan dengan sumber daya yang bertujuan untuk menghasilkkan pendapatan dan arus kas masa depan dan melibatkan aset jangka panjang. Menurut Standar Akuntansi Keuangan (2007) Arus Kas Investasi (Investing Activities) meliputi aktivitas pemberian dan penagihan pinjaman, serta perolehan dan pelepasan invetasi (baik utang maupun ekuitas) serta properti, pabrik dan peralatan. Arus kas yang berasal dari (digunakan untuk) aktivitas investasi adalah arus kas yang disebabkan oleh adanya perolehan dari penjualan surat-surat berharga bukan ekuivalen kas, asset produktif jangka panjang.

\section{Arus kas Pendanaan}

Aktivitas pendanaan adalah aktivitas yang mengakibatkan perubahan dalam jumlah serta komposisi kontribusi modal dan pinjaman entitas Memprediksi klaim atas arus kas masa depan oleh para penyedia modal entitas.

Beberapa contoh arus kas yang berasal dari aktivitas pendanaan adalah : (1) Penerimaan kas dari emisi saham atau instrumen modal lainnya (2) Pembayaran kas kepada para pemegang saham untuk menebus saham perusahaan. (3) Penerimaan kas dari emisiobligasi, pinjaman wesel, hipotik dan pinjaman lainnya (4) Pelunasan pinjaman. (5) Pembayaran kas oleh penyewa guna usaha (lessee) untuk mengurangi saldo kewajiban yang berkaitan dengan sewa guna usaha pembiayaan.

Arus Kas Pendanaan merupakan arus kas yang diperoleh karena adanya kegiatan peminjaman dan pembayaran hutang, perolehan sumber daya dari pemilik perusahaan, serta pemberian imbalan atas investasi bagi pemilik perusahaan (Naimah, 2000). 


\section{Dividend Yield}

Dividend yield merupakan hasil persentase dari keuntungan perlembar saham dibagi dengan harga pasar perlembar saham yang diterima oleh perusahaan. Tingginya suatu dividend yield menunjukan bahwa suatu pasar modal dalam keadaan undervalued, yaitu jika harga pasar saham lebih kecil dari nilai wajarnya, maka saham tersebut harus dibeli dan ditahan sementara dengan tujuan untuk mendapatkan capital gain jika kemudian harganya kembali naik. Kekuatan yang didapat Dividend yield berasal dari kebijakan dalam membagikan return sahamnya yang elah diperoleh perusahaan kepada pemegang sahamnya (Hirt, 2006, dalam Farah Margaretha dan Irma Damayanti, 2008).

\section{Return Saham}

Pengertian saham merupakan tanda penyertaan atau pemilikan seseorang atau badan dalam suatu perusahaan, sedangkan saham secara definitif adalah surat bukti pemilikan bagian modal perseroan terbatas yang memberi hak atas dividen dan lain-lain menurut besar kecil modal yang disetor (Widiatmodjo, 1996dalam Wahidahwati, 2013). Return adalah kuntungan yang dinikmati pemodal atas investasnya. Dengan adanya keuntungan yang dapat dinikmati seorang investor akan tertarik untuk melakukan investasi baik jangka pendek maupun jangka panjang. Menurut Jogiyanto (2003, hlm. 109) menyatakan bahwa return dibedakan menjadi dua yaitu: Return realisasi merupakan return yang telah terjadi berupa capital gain. Return ekspektasi merupakan return yang diharapkan akan diperoleh oleh investor di masa yang akan datang yang berupa deviden.

\section{METODOLOGI PENELITIAN}

Objek dalam penelitian ini adalah laba akuntansi, komponen arus kas, dan dividend yield yang diproyeksikan sebagai variabel bebas sedangkan return saham sebagai variabel terikat dari perusahaan-perusahaan dari sektor pertambangan yang secara konsisten sahamnya telah diperjualbelikan di bursa saham sepanjang periode 2012-2014. Penelitian ini akan meneliti pengaruh laba akuntansi, komponen arus kas, serta dividend yield terhadap return saham pada emiten sektor pertambangan yang listing di BEI dengan periode waktu pada objek selama 3 tahun.

Populasi penelitian ini adalah perusahaan yang terdaftar dalam sektor pertambangan yang terdaftar di Bursa Efek Indonesia periode 2011- 2014 yang terdaftar di Bursa Efek Indonesia. Sampel penelitian diperoleh dengan metode purposive sampling. Berdasarkan kriteria yang ditetapkan diperoleh sampel sebanyak 12 emiten yang sesuai dengan kriteria yang ditentukan yaitu : (1) Perusahaan yang sahamnya tetap aktif beroperasi mulai tahun $2011 \quad-2014$ (2) Perusahaan yang secara konsisten membagikan dividen selama periode penelitian (3) Memiliki data lengkap yang digunakan sebagai variabel dalam penelitian ini dan secara konsisten dilaporkan di BEI Penelitian ini menggunakan data sekunder bersumber dari laporan keuangan tahunan (annual report) perusahaan sektor pertambangan yang terdaftar di BEI pada tahun 2011 - 2014. Teknik pengumpulan data menggunakan teknik dokumentasi. Analisis data dalam penelitian ini menggunakan statistik deskriptif dan menggunakan analisis regresi linear berganda.

\section{HASIL DAN PEMBAHASAN}

\section{Statistik Deskriptif}

Statistik deskriptif disajikan untuk memberikan informasi karakteristik variabel penelitian khususnya mengenai rata-rata (mean), maksimum, minimum dan standar deviasi 
Tabel 1. Statistik Deskriptif Masing-masing Variabel

\begin{tabular}{lccccc}
\hline Variabel & $\mathrm{N}$ & Minimum & Maximum & Mean & Std.Deviation \\
\hline Return Saham & 36 & -0.733 & 1.098 & -0.102 & 0.364 \\
Laba Akuntansi & 36 & -0.945 & 7.926 & 0.678 & 1.746 \\
Arus kas Operasi & 36 & -5.904 & 2.707 & -0.387 & 1.525 \\
Arus kas Investasi & 36 & -2.843 & 4.744 & 0.140 & 1.739 \\
Arus kas Pendanaan & 36 & -14.44 & 15.50 & -0.209 & 3.721 \\
Dividend Yield & 36 & -0.857 & 12.72 & 0.408 & 2.258 \\
\hline
\end{tabular}

Sumber : Pengolahan Data

Tabel 1 menjelaskan nilai statistik deskriptif dari masing - masing variabel yang ada dalam penelitian ini. Variabel Return Saham diukur dengan Perubahan Return, dari 36 sampel penelitian Return Saham memiliki nilai minimum sebesar -0.733 , nilai maximum 1.098 dan memiliki nilai rata - rata sekitar 0.102. Nilai standar deviasi dari Return Saham sebesar 0.364 .

Variabel Laba Akuntansi memiliki nilai minimum sebesar -0.945 dan memiliki nilai maksimum sebesar 7.926. Untuk rata-rata dari Laba Akuntansi sebesar 1.746 dan memiliki standar deviasi sebesar 1.746.

Variabel Perubahan Arus kas Operasi memiliki nilai minimum sebesar -5.904 dan memiliki nilai maksimum sebesar 2.707. Untuk rata-rata dari Perubahan Arus kas Operasi sebesar -0.387 dan memiliki standar deviasi sebesar 1.525 .

Variabel Perubahan Arus kas Investasi memiliki nilai minimum sebesar -2.843 dan memiliki nilai maksimum sebesar 4.744.
Untuk rata-rata dari Perubahan Arus kas Investasi sebesar 0.140 dan memiliki standar deviasi sebesar 1.739 .

Variabel Perubahan Arus kas Pendanaan memiliki nilai minimum sebesar -14.44 dan memiliki nilai maksimum sebesar 15.50 . Untuk rata-rata dari Perubahan Arus kas Pendanaan sebesar -0.209 dan memiliki standar deviasi sebesar 3.721.

Variabel Perubahan Dividend Yield memiliki nilai minimum sebesar -0.857 dan memiliki nilai maksimum sebesar 12.72 . Untuk rata-rata dari Perubahan Dividend Yield sebesar 0.408 dan memiliki standar deviasi sebesar 2.258 .

\section{Uji Normalitas}

Uji normalitas pada penelitian ini menggunakan pengujian plot dan One-Sample Kolmogorov-Smirnov. Berikut adalah hasil tes dengan menggunakan alat bantu berupa software SPSS 20.0 for Windows.

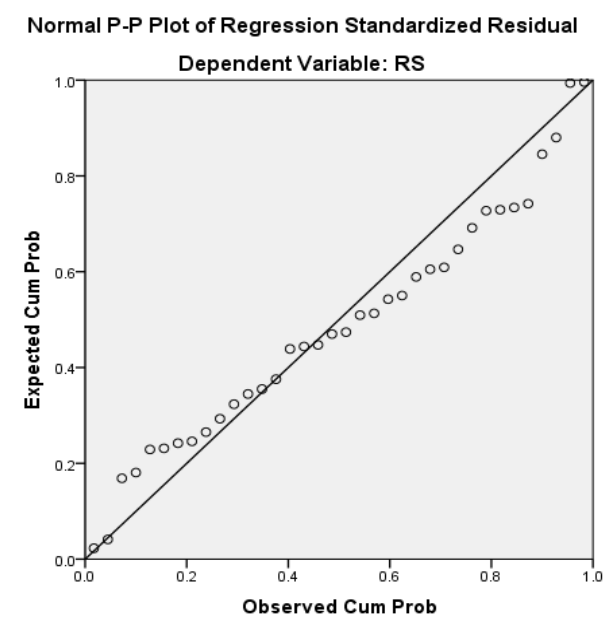

Gambar 1. Plot Distribusi Norma 
Hasil pengujian di atas menunjukkan bahwa data pada penelitian ini berdistribusi normal. Hal ini ditunjukkan dengan plot regresi pada grafik 4.7 dimana titik-titik pada plot tersebut mengikuti garis diagonal sehingga dapat dikatakan bahwa data berdistribusi normal.

\section{Pengujian Multikolinearitas}

Uji asumsi klasik yang kedua adalah uji multikolinearitas. Uji multikolinearitas menguji apakah dalam model regresi ditemukan adanya korelasi antar variabel independen. Model regresi yang baik seharusnya tidak terjadi kolinearitas diantara variabel independen (Ghozali, 2013). Berikut adalah hasil pengujian multikolinearitas pada penelitian ini: yaitu 1,$822 ; 1,741 ; 1,160 ; 1,058 ;$ dan $\quad 1,130$. Maka dapat disimpulkan bahwa variabelvariabel tersebut tidak mengalami multikolinearitas.

\section{Pengujian Heterokedastisitas}

Uji ini bertujuan untuk menguji apakah dalam model regresi terjadi ketidaksamaan variance dari residual satu pengamatan ke pengamatan yang lain, model regresi yang baik adalah tidak terjadi heteroskedastisitas. Untuk mengetahui adanya heteroskedasatisitas digunakan grafik scatter plot yaitu dengan melihat pola-pola tertentu pada grafik, dimana sumbu $\mathrm{X}$ adalah $\mathrm{Y}$ yang telah diprediksi dan sumbu $\mathrm{X}$ adalah residual (Y prediksi - Y sesungguhnya) (Ghozali, 2013,hlm.139). Uji heteroskedastisitas dapat

Tabel 2. Hasil Uji Multikolinearitas

\section{Coefficients $^{\mathrm{a}}$}

\begin{tabular}{|c|c|c|c|c|c|}
\hline \multirow[b]{2}{*}{ Model } & \multicolumn{2}{|c|}{ Unstandardized Coefficients } & \multirow{2}{*}{$\begin{array}{c}\text { Standardized } \\
\text { Coefficients } \\
\text { Beta }\end{array}$} & \multicolumn{2}{|c|}{ Collinearity Statistics } \\
\hline & $\mathrm{B}$ & Std. Error & & Tolerance & VIF \\
\hline $\begin{array}{c}\text { (Const } \\
\text { ant) }\end{array}$ & -.107 & .067 & & & \\
\hline LA & .011 & .049 & .053 & .549 & 1.822 \\
\hline $\mathrm{KO}$ & .010 & .055 & .040 & .574 & 1.741 \\
\hline KI & .049 & .039 & .236 & .862 & 1.160 \\
\hline KP & .019 & .018 & .198 & .945 & 1.058 \\
\hline DY & .010 & .030 & .060 & .885 & 1.130 \\
\hline
\end{tabular}

\section{a. Dependent Variable: RS}

dilakukan dengan melihat scatterplot.

Dalam penelitian ini, nilai VIF dari variabel laba akuntansi, arus kas operasi, arus kas nvestasi, arus kas pendanaan, dividend yield

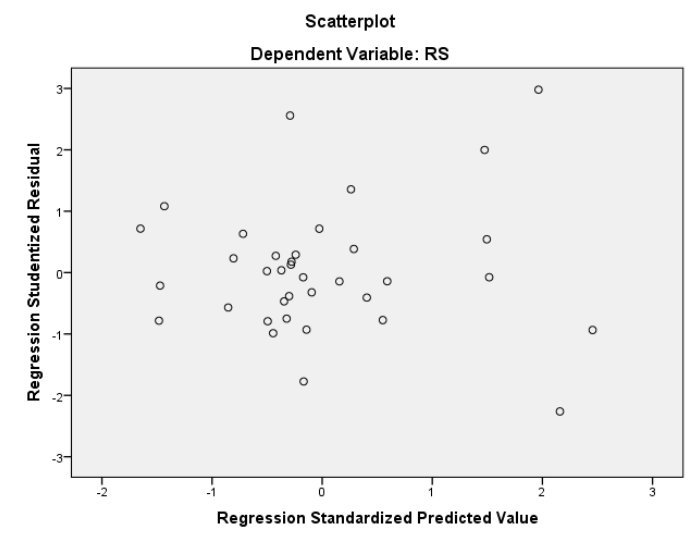

Gambar 2. Hasil Uji Heteroskedastisitas 
Grafik di atas memperlihatkan penyebaran yang tidak teratur. Hal tersebut dapat dilihat dari plot yang terpencar dan tidak membentuk pola tertentu serta titik menyebar di kiri, kanan, atas, dan bawah angka nol. Kriteria tidak terjadi heteroskedastisitas adalah tidak adanya pola tertentu pada scatterplot. Maka dengan demikian dapat ditarik kesimpulan bahwa pada model regresi ini tidak terjadi heteroskedakstisitas.

Pengujian Autokorelasi

Uji autokorelasi bertujuan untuk menguji apakah dalam model regresi linear terdapat korelasi antara kesalahan pengganggu pada periode $t$ dengan kesalahan pengganggu pada periode $\mathrm{t}-1$ (Ghozali, 2013,hlm.110). Berikut adalah output SPSS dari pengujian tersebut :

Tabel 3. Uji Durbin-Watson (DW)

Model Summary ${ }^{b}$

\begin{tabular}{lllll}
\hline Model & R & R Square & $\begin{array}{l}\text { Adjusted } \\
\text { Square }\end{array}$ & $\begin{array}{l}\text { Std. Error of Durbin- } \\
\text { the Estimate }\end{array}$
\end{tabular}

\begin{tabular}{llllll}
\hline 1 & $288^{\mathrm{a}}$ &, 083 &,- 070 &, 037645 & 1.770 \\
\hline
\end{tabular}

a. Predictors: (Constant), DY,KI,KP,KO,LA

b. Dependent Variable: RS

Dalam penelitian ini, cara untuk mengetahui adanya autokoelasi adalah dengan menggunakan Durbin-Watson (DW) Statistic.
Dimana terdapat kriteria untuk menentukan adanya autokoleralasi atau tidak dengan menggunakan kriteria:

\section{Tabel 4. Kriteria}

\begin{tabular}{cc}
\hline Kurang dari 1,10 & Ada Korelasi \\
\hline $1,10-1,54$ & Tanpa Kesimpulan \\
$1,55-2,45$ & Tidak ada autokorelasi \\
$2,46-2,90$ & Tanpa Kesimpulan \\
Lebih dari 2,91 & Ada Korelasi \\
\hline
\end{tabular}


Dengan nilai Durbin-Watson (DW) sebesar 1,770 maka dapat disimpulkan bahwa variabel-variabel tersebut tidak ada autokorelasi.Analisis Regresi Linear Berganda

Untuk mengetahui bagaimana pengaruh dari variabel-variabel independen terhadap variabel dependen pada penelitian ini, maka data diolah dengan menggunakan metode analisis regresi berganda. Berdasarkan olah data dengan program SPSS, maka didapat hasil:

Tabel 5. Output SPSS Regresi Linear Berganda Coefficients $^{\mathrm{a}}$

\begin{tabular}{|c|c|c|c|c|c|c|}
\hline & \multirow[b]{2}{*}{ Model } & \multicolumn{2}{|c|}{$\begin{array}{l}\text { Unstandardized } \\
\text { Coefficients }\end{array}$} & \multirow{2}{*}{$\begin{array}{c}\text { Standardized } \\
\text { Coefficients } \\
\text { Beta }\end{array}$} & \multirow[b]{2}{*}{$\mathrm{t}$} & \multirow[b]{2}{*}{ Sig. } \\
\hline & & B & Std. Error & & & \\
\hline 1 & (Constant) & -.107 & .067 & & $\begin{array}{r}- \\
1.593\end{array}$ & .122 \\
\hline & LA & .011 & .049 & .053 & .224 & .825 \\
\hline & $\mathrm{KO}$ & .010 & .055 & .040 & .174 & .863 \\
\hline & KI & .049 & .039 & .236 & 1.255 & .219 \\
\hline & $\mathrm{KP}$ & .019 & .018 & .198 & 1.102 & .279 \\
\hline & DY & .010 & .030 & .060 & .324 & .748 \\
\hline
\end{tabular}

a. Dependent Variable: RS

Sumber:SPSS 22.0. Data diolah

Dari tabel di atas diketahui bahwa nilai konstanta adalah sebesar -0,107, nilai LA sebesar 0,011, nilai $\mathrm{KO}$ sebesar 0,010, nilai KI sebesar 0,049, nilai KP sebesar 0,019 dan nilai DY sebesar 0,10. Berdasarkan nilai-nilai tersebut, maka dapat dibentuk persamaan regresi sebagai berikut:

$$
\begin{aligned}
\mathrm{Y}^{\prime}=-0,107 & +0,011 \mathrm{X}_{1}+0,010 \mathrm{X}_{2} \\
& +0,049 \mathrm{X}_{3}+0,019 \mathrm{X}_{4} \\
& +0,010 \mathrm{X}_{5}+\varepsilon
\end{aligned}
$$

Persamaan regresi diatas mempunyai makna Nilai konstanta sebesar -0,107 artinya jikavariabel Independen yaitu LA (X1), KO (X2), KI (X3), KP (X4), DY ( $\left.\mathrm{X}_{5}\right)$ bernilai konstan atau sama dengan nol, maka nilai return saham adalah sebesar $-0,107$.

\section{Pengaruh Laba Akuntansi terhadap Return Saham}

Hasil analisis tersebut menunjukkan pengaruh Positif dimana semakin tingginya tingkat Laba Akuntansi, maka akan Menaikan Tingkat Return Saham. Artinya bahwa Laporan laba rugi berguna sebagai alat untuk mengevaluasi kinerja masa lalu perusahaan, dan memberikan dasar untuk memprediksikan kinerja masa depan.

\section{Pengaruh Arus Kas Operasi terhadap Return Saham}

Hasil analisis menunjukkan pengaruh Positif dimana semakin tingginya tingkat Arus kas Operasi, maka akan Menaikan Tingkat Return Saham Dengan demikian Arus kas operasi dapat memberikan sinyal positif kepada investor mengenai prospek dan kinerja perusahaan di masa depan melalui aktivitas operasinya, sehingga investor tertarik membeli saham tersebut. Adanya aktivitas tersebut menyebabkan harga saham mengalami kenaikan yang pada akhinya meningkatkan return sahamnya.

\section{Pengaruh Arus Kas Investasi terhadap Return Saham}

Hasil analisis tersebut menunjukkan pengaruh Positif dimana semakin tingginya tingkat Arus kas Investasi, maka akan Menaikan Tingkat Return Saham. Artinya bahwa peningkatan investasi berhubungan dengan peningkatan arus kas masa mendatang dan berpengaruh positif terhadap return saham Adanya peningkatan arus dari aktivitas investasi akan menarik investor untuk melakukan aksi beli saham yang akan 
meningkatkan harga saham yang pada akhirnya akan meningkatkan return saham.

\section{Pengaruh Arus Kas Pendanaan terhadap Return Saham}

Hasil analisis menunjukkan pengaruh Positif dimana semakin tingginya tingkat Arus kas Pendanaan, maka akan Menaikan Tingkat Return Saham. Artinya apabila investor mengetahui arus kas pendanaan perusahaan cenderung tinggi maka semakin tinggi kepercayaan investor pada perusahaan tersebut dan semakin besar pula return sahamnya.

\section{Pengaruh Dividend Yield terhadap Return Saham}

Hasil analisis tersebut menunjukkan pengaruh Positif dimana semakin tingginya tingkat Dividend Yield, maka akan Menaikan Tingkat Return Saham.maka perusahaan mampu menghasilkan keuntungan yang besar pula dan akan berpengaruh secara positif terhadap return saham. Adanya peningkatan Rasio Dividend Yieldakan menarik investor untuk melakukan aksi beli saham yang akan meningkatkan harga saham yang pada akhirnya akan meningkatkan return saham.

\section{SIMPULAN}

Berdasarkan hasil penelitian mengenai "Pengaruh Laba Akuntansi, Komponen Arus Kas, danDividend Yield Terhadap ReturnSaham" (Studi Pada perusahaan sektor pertambangan Periode 2012-2014)" maka dapat ditarik simpulan sebagai berikut :

Laba Akuntansi berpengaruh Positif terhadap Return saham. Artinya bahwa semakin tinggi tingkat Laba akuntansi dalam laporan laba rugi, maka akan meningkatkan Return saham.

Arus kas operasi berpengaruh Positif terhadap Return saham. Artinya Investor merespon tingkat pertumbuhan pada arus kas operasi dan digunakan sebagai dasar pengambilan keputusan investor dalam memperoleh return saham.

Arus kas investasi berpengaruh Positif terhadap Return saham. Artinya Investor merespon tingkat pertumbuhan pada arus kas investasi dan digunakan sebagai dasar pengambilan keputusan investor dalam memperoleh return saham.

Arus kas pendanaan berpengaruh Positif terhadap Return saham. Artinya Investor merespon tingkat pertumbuhan pada arus kas pendanaan dan digunakan sebagai dasar pengambilan keputusan investor dalam memperoleh return saham.

Dividend Yield berpengaruh Positif terhadap Return saham. Artinya apabila perusahaan membagikan dividen yang tinggi maka pemegang saham akan memperoleh return yang tinggi, begitu pula sebaliknya.

\section{DAFTAR PUSTAKA}

Akmal, H. (2011). Pengaruh Economic Value Added, Market Share, Earnings, dan Net Cash Flow Terhadap Return Saham (Studi Pada Perusahaan Manufaktur jenis Consummer Di Bursa Efek Indonesia 2004-2007). Jurnal Wira Ekonomi Mikroskil, 1(2).

Belkaoui, R. A. (2000). Teori Akuntansi. Jakarta: Salemba Empat.

Brigham, E.F., Houston, J.F. 2001. Fundamentals of Financial Management. Ninth Edition. Harcourt.

E Kieso, Donald, Jerry J, Weygandt and Teery D Warfield, (2011). Intermediate Accounting (12th ed.). Erlangga

E Tandelilin. (2007). Analisis investasi dan manajemen portofolio. Yogyakarta: BPFE Yogyakarta.

Farah Margaretha \& Irma Damayanti. (2008). "Pengaruh Price Earnings Ratio, Dividend Yield, dan Market to Book Ratio Terhadap Stock Return di BEI". Jurnal Bisnis dan Akuntansi, 10 (3), Desember, pp. 149-160.

Ghozali, Imam. (2013). Aplikasi Analisis Multivariate Dengan Program SPSS edisi tujuh. Semarang: Badan Penerbit Universitas Diponegoro.

Graham Smart Megginson. (2010). Corporate Finance Third Edition: Penerbit: SouthWestern.

Harahap. Sofyan, (2011). Analisa Kritis Atas Laporan Keuangan. Jakarta: Bumi Aksara 
Harjono Sunardi, (2010). "Pengaruh Penilaian Kinerja dengan ROI dan EVA terhadap Return Saham pada Perusahaan yang Tergabung dalam Indeks LQ 45 di Bursa Efek Indonesia". Jurnal Akuntansi, 2 (1) Mei 2010 pp. 70-92

Husnan, Suad. (2005). Dasar-Dasar Teori Portofolio dan Analisis Sekuritas (4th ed.), Yogyakarta: BPFF.

Ikatan Akuntan Indonesia.(2007). pernyataan Standar Akuntansi Keuangan No. 2, Jakarta. Salemba Empat.

Ikatan Akuntan Indonesia.(2009). Standar Akuntansi Keuangan edisi revisi 1 januari 2009, Jakarta: Salemba Empat

Islahuzzman. (2012). Istilah-istilah Akuntansi \& Auditing. (1th ed.). Bumi Aksara. Jakarta

Ita Trisnawati. (2009). "Pengaruh Economic Value Added, Arus Kas Operasi, Residual Income, Earnings, Operating Leverage dan Market Value Added Terhadap Return saham". Jurnal Bisnis dan Akuntansi, 11 (1), April, pp.65-78.

Judy Rayburn, (1986). "The Association of Operating Cash Flow and Accruals with Security Returns". Journal of Accounting Research. July, 24 pp. 112-133

Merton H.Miller \& Kevin Rock, (1985). "Dividend Policy under Asymmetric Information". Journal of Finance. September, 40 1031-1051.

Michell Surharli. (2005). "Memprediksi Tingkat Pengembalian Investasi Pada Equity Securities Melalui Rasio Probabilitas, Likuiditas, dan Hutang Pada perusahaan Publik Di Jakarta”. Jakarta: Jurnal SNA.

Robert Ang. (1997). Buku pintar Pasar Modal Indonesia. Jakarta: Mediasoft Indonesia.

Sawidji Widoatmodjo. (2012). Cara Cepat Memulai Investasi Saham Panduan Bagi Pemula. Jakarta: PT Elex Media Komputindo

Soemarso.S.R. (2005). Akuntansi Suatu Pengantar buku kedua. Jakarta: Salemba Empat.

Stephen H. Penman. (1991). "An Evaluation of Accounting Rate-of-return" Journal of Accounting. April, 6 pp. 233.
Subramanyam. (2010). Analisa Laporan keuangan. Jakarta: Salemba Empat.

Sugiyono. (2013). Metode Penelitian Kuantitatif, kualitatif,dan R\&D. Bandung: Alfabeta.

Sunarto. (2009). "Teori Keagenan dan Manajemen Laba". Jurnal Kajian Akuntansi. Semarang. Pp. 13-28.

Suriani Ginting. (2011). “Analisis Pengaruh Pertumbuhan Arus kas, dan Laba Akuntansi terhadap Return saham pada Perusahaan LQ 45 Di BEI". Jurnal Wira Ekonomi, 1 (2), Oktober.

T Darmadji, HM Fakhruddin. (2011). Pasar Modal Di Indonesia, (3th ed.). Jakarta: Salemba Empat.

Tatang Ary Gumanti dan Novi Puspitasari. (2005). "Siklus Kehidupan Perusahaan dan Kaitannya dengan Investment Opportunity Set, dan Risiko dan Kinerja Finansial". Surabaya. Jurnal Riset Ekonomi dan Bisnis, 8 (1).

Triyono dan Jogiyanto, 2000. "Hubungan Kandungan Informasi Arus Kas , Komponen Arus Kas dan Laba Akuntansi dengan Harga atau Return Saham". Yogyakarta Jurnal Riset Akuntansi Indonesia, 3 (1), pp. 54-68.

Umar, Husein. (2008). Metode Penelitian untuk Skripsi dan Tesis Bisnis Edisi Kedua. Jakarta: PT RajaGrafindo Persada.

Z Naimah. (2000). "Kandungan Informasi Laba Akuntansi dan Arus Kas terhadap Harga Saham". Padang. - Jurnal Akuntansi. 


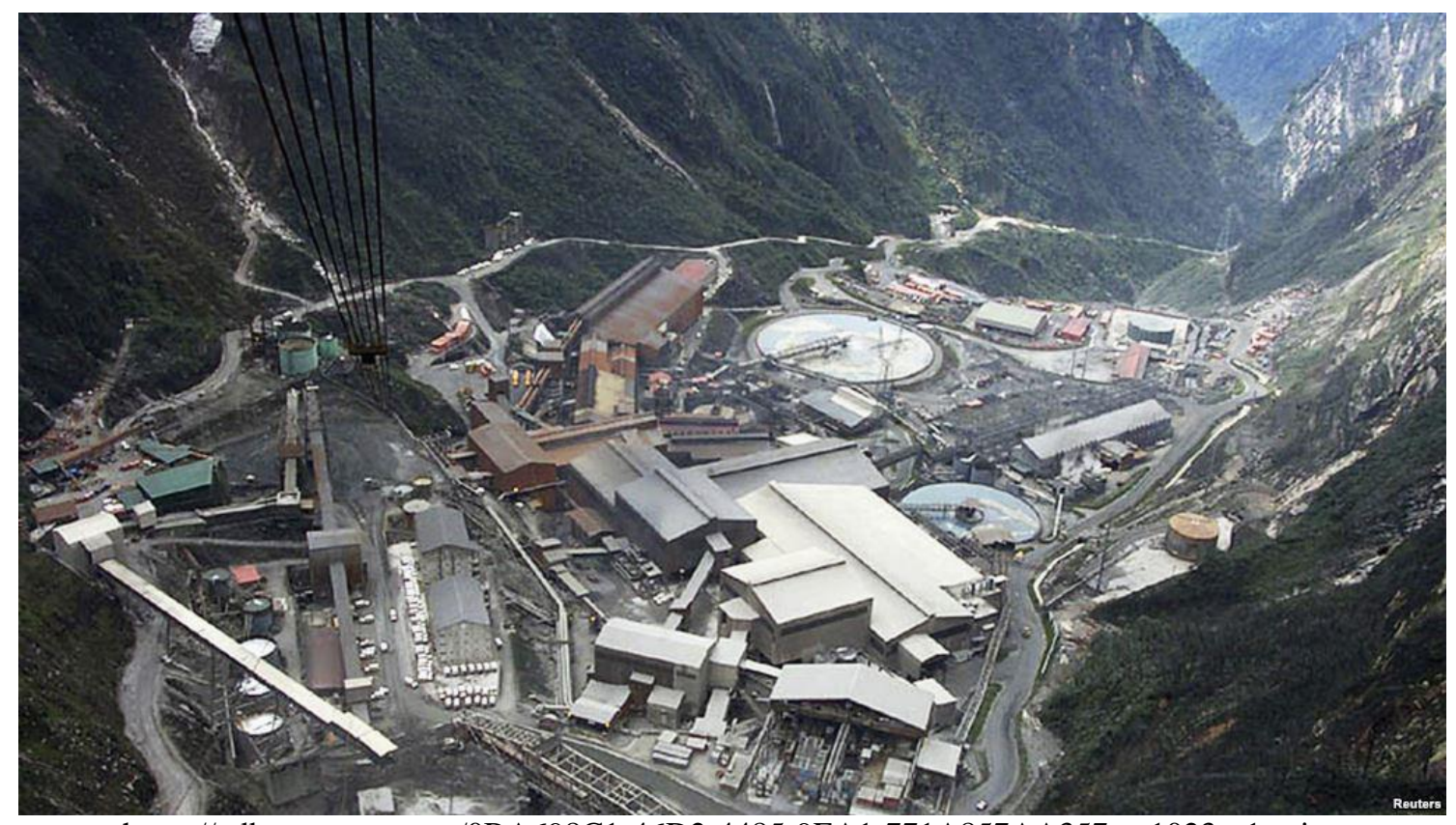

https://gdb.voanews.com/0BA698C1-46D2-4485-9EA1-771A857AA357_w1023_r1_s.jpg

Foto udara tambang raksasa yang dikelola oleh perusahaan AS, Freeport-McMoran Cooper \& Gold Inc., yang terletak di operasi pertambangan Grassberg, di provinsi Papua, Indonesia (Juli 2005). (foto: REUTERS/Stringer/Arsip). 